\title{
Prioritising local Housing Needs through Land-USe Planning in RuRal Areas: Political Theatre or Amenity Protection?
}

\author{
Nick Gallent ${ }^{1}$, Iqbal Hamiduddin ${ }^{1}$, Phoebe Stirling ${ }^{1}$ and John Kelsey ${ }^{2}$ \\ ${ }^{1}$ UCL Bartlett School of Planning \\ ${ }^{2} \mathrm{UCL}$ Bartlett School of Construction and Project Management
}

\begin{abstract}
This paper examines housing investment pressures and the local planning response in St Ives, Cornwall, where a Neighbourhood Development Plan introduced a principal residence restriction affecting all new-build homes in the locality in 2016. Ostensibly, the objective of this policy is to reserve new-build housing for local residents, thereby delivering improved housing market access for those needing to live and work in the area, who are seen to have greater claim on local resources. However, our study of the development and anticipated impacts of 'Policy H2', drawing on semi-structured interviews, highlights concerns amongst long-term residents and working households as to the economic impacts of the policy relative to its impacts on housing access. Greater support for the policy was found to exist among in-migrant and retired households, who view the policy as a means of slowing development, preserving local character, and defending property values. Evidence from prior experiments with residence restrictions in the Lake District and in Wales suggest that an overall reduction in house building (triggered by a shrinking of the market of eligible homebuyers) and a shift in demand by investors from new homes to the second-hand market can elevate house-prices and reduce overall housing affordability. Local needs planning policies may be politically expedient, with local politicians responding to a call to action, but they also carry the risk of unintended consequences.
\end{abstract}

\section{Introduction}

Housing inequality remains an important and widespread rural challenge across many advanced and emerging economies (Gallent and Scott, 2019). In England, as in other countries where new development is highly regulated, counter-urbanisation and the transfer of urban wealth to scenic rural localities often produces market asymmetry: intense demand for housing on the one hand, but a low rate of supply on the other, which results from the priority placed on landscape protection. Unequal competition for scarce housing resources, between groups deriving higher incomes from urban jobs and those with lower incomes from rural occupations, is an important and regular dynamic observed in 
many rural housing markets. Alongside supply constraint, unequal competition is viewed as the 'essence' of the rural housing problem (Shucksmith, 1981); an issue accentuated in localities with greatest scenic or amenity value, which often excites competition for housing between higher earners, causing further price inflation in markets severely supply-constrained by planning restrictions (Gkartzios and Ziebarth, 2016). Within these localities, political debate frequently focuses on how new supply can be unlocked for local need, but without impacting on rural character and amenity - to be protected through otherwise strict rationing of development (Gallent and Robinson, 2012). Some form of intervention in the operation of the market is often presented as the answer to delivering against 'local needs' and setting 'local priority' (Gallent and Robinson, 2011; 2012). One possibility is to produce a special class of 'affordable housing' for local households on lower incomes. Another is to limit and reserve new-build housing for those same local households, thereby meeting the twin objectives of slowing development and extending housing access to relatively weaker domestic property classes.

This paper analyses an attempt to prioritise local housing needs in rural areas by introducing a 'principal residence' clause as a planning condition for the development of new housing. It begins by examining the role of local planning in responding to housing pressure in such areas before turning attention to the underlying politics of intervention. It proposes that local needs policies are frequently an act of political theatre and dominated by the objective of amenity protection rather than the goal of making housing more affordable or accessible to local families and workers. The paper's empirical focus is the coastal town of St Ives in Cornwall where, following a referendum into the adoption of its neighbourhood development plan in 2016, a policy was introduced that restricts the granting of planning permission to new homes that will be occupied by 'full time residents'. This recent move can be regarded as part of a wider 'backlash' against second homes or non-resident property ownership that has accelerated across many countries in recent years. St Ives' stance is by no means unique; other localities in the southwest of England are adopting similar occupancy strategies, whilst internationally, governments in countries including Switzerland, France, China and the United States have recently introduced measures in response to surging second home ownership over recent decades (Hilber and Schöni, 2016). Similar policies have previously been introduced to other localities in England and Wales and seem to have 
impacted on development activity in a complex way, reducing the quantity of new-build housing coming forward and exerting upward pressure on house prices (Capstick, 1987; Shucksmith, 1990). Given that observed reality, the paper explores the deeper politics of local planning intervention and its broader mix of goals.

\section{The role of planning}

The rural housing challenge is frequently viewed as a planning problem. It is the planning system that prioritises amenity protection over housing need and it is the planning system, therefore, that corrals housing demand into pressure points and impacts on prices. For that reason, the search for remedies often begins with land-use planning. Two broad solutions (short of the deregulation of development) have gained traction: the first is to use the system to procure non-market housing. This has been achieved through 'rural planning exceptions' (permission for affordable homes on farmland, as an exception to usual planning rules, Gallent and Bell, 2000) in smaller village locations or through negotiated developer contributions from larger developments, often in market towns. Neither of these mechanisms has been equal to the scale of the rural housing challenge and both tend to reinforce inequalities by separating lower and higher income groups. The second solution has been to restrict the occupancy of market housing to those households with a demonstrable 'local connection'. The main difference between these approaches is that one seeks to increase (non-market) supply whilst the other attempts to retain a proportion of market housing for local need, without increasing new supply. In practice, this means that the second approach may have broader market impacts, affecting local house prices by shifting the price incentives to develop land and thereby influencing supply as development activity subsides. Seeking contributions of affordable housing from developers will increase development costs, but these can be factored into developer business models. Occupancy restrictions, if generalised across jurisdictions, will bring more profound change to the housing market and development activity.

Those changes have been studied before. Both Shucksmith (1981; 1990) and Capstick (1987) examined the housing market and development impacts of using planning restrictions (conditional permission for new build) to prioritise local needs above the demands of buyers wishing to retire or purchase second 
homes in the English Lake District in the 1970s and 1980s. In 1977, the Lake District Special Planning Board issued a draft plan which set out its intention to 'restrict completely all new development to that which can be shown to satisfy a local need' (LDSP, 1977) and began using Section 52 Planning Conditions to that end. A broader policy with that same stated purpose was then written into the Cumbria and Lake District Joint Structure Plan three years later (LDSP and CCC, 1980) and sought to restrict the occupancy of all new build housing to 'full time residents'. The policy was not without its critics. The Panel Report following the 'examination in public' of the Joint Structure Plan concluded that it was 'unreasonable' to use 'planning powers to attempt to ensure that houses should only be occupied by persons who are already living in the locality', adding that planning should be 'concerned with the manner of the use of land, not the identity or merits of the occupier' (DoE, 1981). Debate on the function of planning in England has moved on since then: planning is regularly called upon to procure affordable homes for target groups. That was not the case, however, in 1981 and two years later the Secretary of State deleted the full-time residency / local need policy from the Joint Structure Plan. Yet the policy had remained in force, first in the Draft National Park Plan and then in the Joint Structure Plan, for a full seven years between 1977 and 1984.

During these seven years, the impacts of the policy were studied by Shucksmith, the results being published in two books - No Homes for Locals? (1981) and in greater analytical detail in Housebuilding in Britain's Countryside (1990). The author made a number of observations. First, households seeking second homes in the Lake District were largely undeterred by the restriction; they had always preferred second hand property anyway (older village homes rather than new build) but now demand from them became entirely concentrated in that segment of the market. Second, although new build housing was now targeted at 'local need' - at full time residents - the supply of that housing began to dip. It was observed that 'builders ceased speculative residential development, partly because of the uncertainties raised by the new policy, but principally because of the greater difficulty of acquiring suitable land with planning permission' (p. 122). Third, the aggregate impact across the entire housing market comprising second hand housing and a declining quantity of new build - was a slightly faster rate of house price inflation. This, combined with the restriction on non-local purchase in the market for new 
build, choked off some of the external demand. Some aspiring second home buyers found the Lake District suddenly too expensive and shifted their attention elsewhere, outside the area of restriction.

But overall, price adjustments for second hand and new build property were largely balanced out across the market. Excess external demand shifted entirely to second hand property, benefiting existing homeowners. That same demand was removed from the new build segment, but prices there were largely unaffected owing to changes in land values, development activity and therefore reduced supply. Indeed, 'local people who could afford to buy new housing will have found prices roughly the same as before, once the shifts in the demand and supply schedules had worked through' (p. 123). Those unable to access the market before were not assisted greatly by the policy.

These impacts can be expressed diagrammatically. Figure 1 shows the segmentation of the housing market into its new build and second hand components. A restriction on the occupancy of new build housing (affecting the purchase of, and market for, that housing) will cause the new build demand curve to be replaced by a subset comprising local demand which has a lower income elasticity ( $\mathrm{D}$ is pushed down on the left). The displaced external demand is then added to the second hand market (D is pushed up on the right). This assumes that local amenity value underpins life-style choice - for which there is considerable demand - and that the supply curve of second hand housing is therefore relatively priceinelastic. This results, on the right, in a large second hand excess demand which is choked off by a steep price rise. On the left, the residual value of land under development falls, threatening some schemes (S adjusts downwards) or forcing re-design for a lower income market. The willingness of land owners to make land available for development under the new planning rules may decline; some compensation is possible if public land can be brought forward or if developers hold significant land banks and can be encouraged, in some way, to keep developing housing for the now restricted (and tightly bounded) market. But there is a danger, of course, that landowners and developers will simply sit it out, waiting for a successful challenge in the Courts to the rules or for some future change. Developers may also shift their attention to opportunities elsewhere, causing land values outside the area of restriction to increase. Jackson and colleagues (1994) have shown that such constraints on land release (linked to landowner behaviour) will affect the distribution of house building activity, the type 
and timing of housing development and result in local price adjustments (see also Shucksmith, 1990: 122).

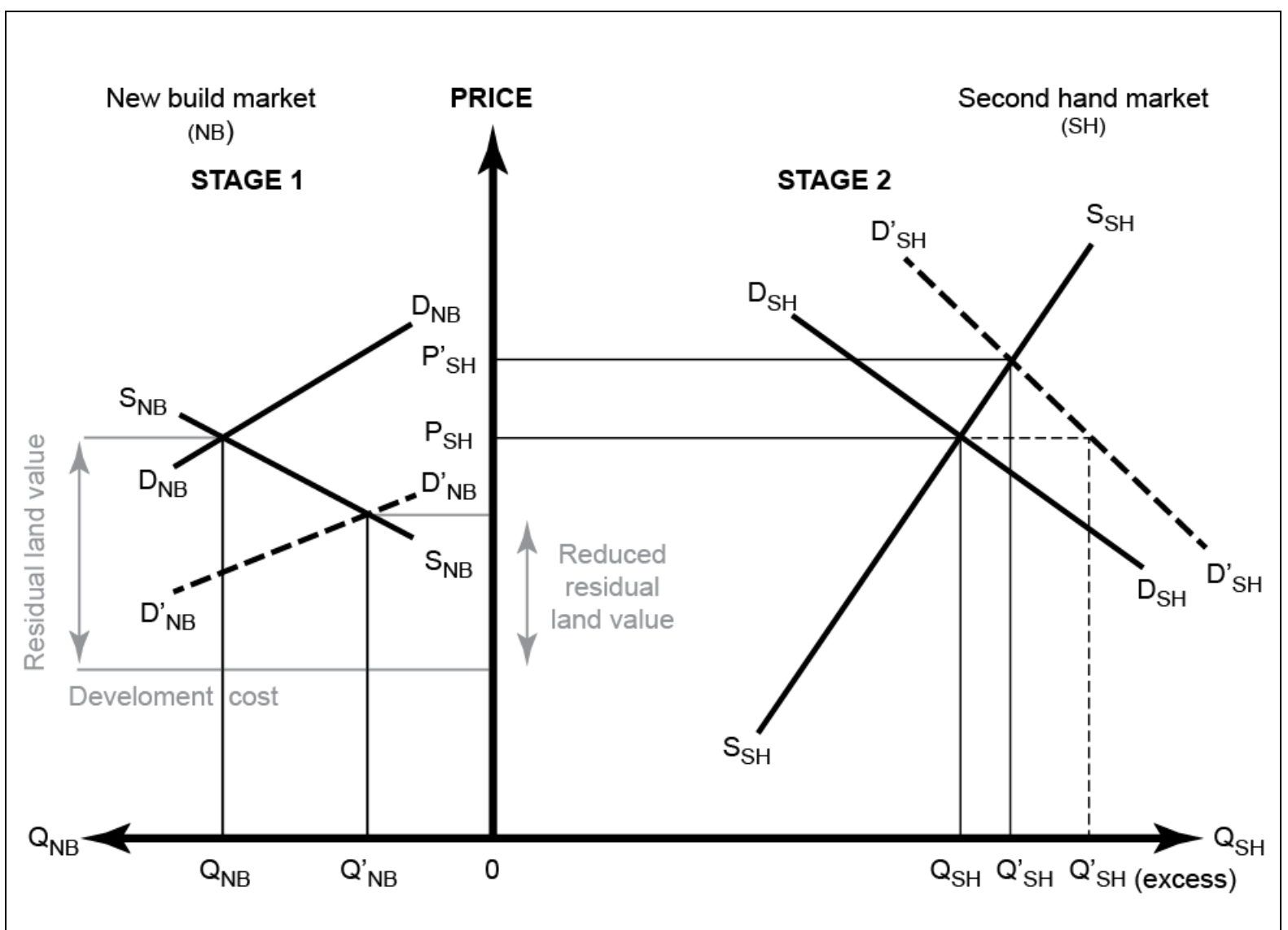

Figure 1: Segmentation of the housing market into its new build and second-hand components - and impact of market restriction affecting the new build segment (source: authors)

Because of these changes to the development context on the left of the diagram, and a displacement of external demand to the right, local access to the second hand market will be reduced possibly by more than any increase in access to the new build market, depending on relevant elasticities. Longer term supply of development land (if the restriction remains unchanged) may be reduced or land may eventually be supplied for non-housing use. This modelling of shifts in supply, demand and residual land values explains the key outcomes observed by Shucksmith in the Lake District (although all contexts are of course different): price rises in the second hand market and reduced access for local households, a reduction in the supply of new build development (and corresponding price adjustments) and a relocation of development interest to other places. The observed outcomes appeared broadly favourable for existing homeowners, who saw the value of their property rise faster than it would have 
done without the restriction. But those seeking to buy for the first time, or rent, saw little or no benefit from the policy and had less chance of accessing the second hand market than before.

\section{The role of politics}

If such planning solutions have easily predictable impacts, which clearly deviate from those intended, why is there a recurrent recourse to such solutions? This question is explored in this paper and two propositions are tested: first, there is a political rationale for action - to be seen to do something in the face of a seemingly intractable problem that has more fundamental 'up-stream' causes (including a switch of capital into housing, as investment, over the last 50 years); and second, that amenity protection rather than delivering housing justice is the principal, albeit obscured, goal of such restrictions.

In relation to the first question, housing is the consummate 'wicked problem', with housing stress and inequality having complex causes that incubate in a political space in which the function of housing as home or asset - and housing justice (whether deliverable through the market or through public intervention) are perpetually contested. Planning solutions seek to shape local outcomes at the end of a complex process in which the role of housing, up stream, is determined by fiscal governance (the tax treatment of residential property) and by the function and market for housing in a wider political economy. In that economy, house price inflation has been viewed as a good thing, supporting public revenues (especially from transaction taxes) and boosting consumer confidence. Government and the general public want house prices to stay on an upward track but do not want the political inconvenience of local conflict and the spectacle of 'local people' pushed out of the housing market. There is therefore a degree of political support for local solutions to housing stress that do not upset the bigger applecart. Therefore, local interventions of the sort seen in the Lake District have garnered greater political support in recent years, and since the introduction of neighbourhood planning through the 2011 Localism Act, communities have been provided with the tools with which to directly shape local planning policies (Gallent et al, 2013). Government's commitment to neighbourhood planning, and onward to neighbourhood-based solutions, can be read as faith in the local design and implementation of policy that deviates from a national position on key issues. However, that national position (expressed through fiscal policy and the deregulation of markets) tends to overpower local solutions before they have even 
been formulated. Restrictions on housing occupancy, delivered through (neighbourhood) planning seems to be a good example of this and within that context, local action is reduced to political theatre: being seen to act and therefore assuaging the concerns of local voters. To what extent then, are occupancy-based policies purely 'political'?

Concerning the second proposition ('occupancy restrictions seek amenity protection by reducing the overall volume of development'), the underpinning logic here is that those already benefitting from the asset value of housing (which is, in part, secured through the quality of local amenity) seek to 'raise the drawbridge' on further in-migration and therefore additional development that might spoil the character and amenity qualities that sustain property values. This is a familiar thesis and one which has been addressed in a broad literature on rural housing outcomes in the context of counter-urbanisation pressures. It supposes a degree of understanding (of land-planning interactions) and cynicism on the part of wealthier households and also supposes a prioritisation of amenity over economic development.

\section{St Ives, Cornwall}

On the 6 May 2016, the residents of St Ives voted in a referendum on a neighbourhood development plan, unremarkable but for one key policy: H2 Full Time Principal Residence Requirement (St Ives Town Council, 2016). Like many coastal towns in Cornwall, St Ives has a high number of second homes - a quarter of its total housing stock - and there has been growing concern over their impact for a number of years. They are viewed by many as a cause of escalating house prices and declining affordability, locking a great many 'local households' out of the housing market. Their harshest critics view them as agents of 'financial cleansing' (The Economist, 2016). It is in that context that 'new open market housing without a restriction to ensure its occupation as a full time principal residence (occupied for at least 270 days per year) will not be permitted' (St Ives Town Council, 2016). Guaranteed full time occupancy will come from the imposition of a planning condition on new development and anyone found to be occupying a home for fewer than the minimum number of days each year will find themselves on the wrong end of a 'breach of condition order' and subsequently a 'planning contravention notice'. 
Second homes express deeper and wider housing investment pressures in Cornwall. They are the tip of a large iceberg. Below the surface, Cornwall has attracted significant numbers of retiring households since the 1960s as well has an inflow of life-style downshifters. In composite, counter-urbanisation has brought significant change to many parts of the county and sparked a lively debate on how such changes, and their perceived causes, might be managed. The response in St Ives is one of the latest reactions to pressures on Cornwall's housing market.

Under the Localism Act 2011, local communities can produce Neighbourhood Development Plans (NDPs) which, if passed by an independent examiner and by a majority of voters in a referendum, can be adopted (or 'made') by the local planning authority (LPA), thereafter providing part of the basis of determining planning applications in the area. A referendum held on $6^{\text {th }}$ May 2016 posed the following question to the local electorate: 'Do you want Cornwall Council to use the neighbourhood plan for St Ives to help it decide planning applications in the neighbourhood area?' In response, $83 \%$ of voters backed this proposal from a $42.7 \%$ turnout (Guardian, 2016), meaning that the NDP - and Policy H2 therein - will apply in the area until 2030. The policy immediately garnered opposition - particularly from local developers. This led to a Judicial Review. The examiner of the St Ives NDP noted her own concerns in weighing the merits of the proposal:

The inclusion of a restrictive occupancy condition (policy H2) has given me considerable concern. The intended consequence of this policy is to prevent any new dwelling within the plan area being used as a "second home" or as self-catering holiday accommodation. Reading the responses to this proposed policy it is evident that feelings in the community are running high and comment and concerns have been expressed on a national level.

However, after 'much deliberation, and on balance' McCann concluded that: 
Due to the adverse impact on the local community/economy of the uncontrolled growth of second homes the restriction of further second homes does in fact contribute to delivering sustainable development (McCann, 2015: 30)

\section{Research Approach}

Interviews were undertaken with key stakeholders in Cornwall and St Ives in 2016, within 6 months of the referendum and following the outcome of the Judicial Review into the inclusion of the occupancy restriction in St Ives' Neighbourhood Plan. Interviews explored the propositions outlined earlier, that occupancy restrictions are a form of political theatre, that the underlying objective is to limit development and protect amenity, and also that such measures cannot deliver their stated aims given the complexity of the planning-development-land interactions. A total of twelve stakeholders took part in ten semi-structured interviews (Table 1), one of which was conducted as a group interview (S01), and the remainder on a one-to-one basis:

\begin{tabular}{|l|l|l|}
\hline Interview Subject & Code & Local / National \\
\hline NDP Housing Topic Group (3 interviewees) & S01 [p1,p2,p3] & Local \\
\hline Town Council & S02 & Local \\
\hline Estate Agent & S03 & Local \\
\hline Estate Agent & S04 & Local \\
\hline Estate Agent & S05 & Local \\
\hline Cornwall County Council & S06 & Local \\
\hline Development Manager (Arch) & S07 & Local \\
\hline Professional Body & S08 & National \\
\hline Landowners' Representative & S09 & National \\
\hline Valuation Surveyor & S10 & Local \\
\hline
\end{tabular}

Table 1: List of interviewees and coding 
Most of the interviews were undertaken over the telephone, recorded and transcribed. Some were undertaken in Cornwall, and again recorded and transcribed. Interviews were structured around five themes that sought to track the narrative of policy development in the town. These themes were:

1. The pathways to intervention - concerned with the pressures and debates that foregrounded action; how housing problems were conceived (by different groups) and how their impacts were understood (again, by different groups);

2. The logic of intervention - concerned with the focus on land-use planning as an instrument of control and different conceptions of how planning restriction might interact with the land market, with house prices and with broader housing outcomes for specific groups;

3. The evidence base - concerned with the extent to which proponents and designers of the intervention had explored available evidence of the policy's function and likely effects ahead of implementation;

4. Observed and anticipated impacts - concerned with early evidence of changes in the land market and market activity that might, in due course, influence housing outcomes;

5. Interactions between market segments - concerned, more specifically, with signs of impact focused on new build activity and the market for second hand housing and, therefore, with the validity of existing theory used to explain the market segmentation arising from intervention in new build.

Embedded in these five themes are a concern for testing our key propositions centred on political theatre, amenity protection and general policy effectiveness. In the section that follows, we track through those themes before returning to a broader consideration of the key propositions.

\section{Research Findings}

\section{The Pathways to Intervention}

A Steering Group of St Ives Town Council was established early in 2013 and tasked to formulate priorities and guiding principles for a Neighbourhood Development Plan. It canvassed residents for their views on priority issues for the new plan. Twenty per cent of households (roughly 1,000) responded to the Steering Group's household survey in the autumn of that year and many expressed the 
view that new housing being built in and around the town was unsuited to 'local needs'. In particular, not enough affordable housing was being delivered - a view that was confirmed in follow-up workshops with residents (St Ives NDP HTG, 2014). The survey also captured a general antipathy towards further development in the town, which was later confirmed during interviews: 'yes, we need more affordable homes, but we don't want any more development' (S01 [p1]). The pace of recent development had perhaps contributed to this view. The same interviewee pointed out that $60 \%$ of the total housing allocation contained in the 20-year Local Plan had been delivered in the preceding 5 years, leading to a perception of rapid development and change. Attaching a full-time residency clause to new planning permissions was conceived by the Housing Topic Group (HTG) as way to calm the market pressure behind higher development pace and focus new build on the local market. The Group had been inspired by the introduction of similar approaches elsewhere in the southwest of England and further afield:

We looked at other areas as well; the Lake District and Lynton-Lynmouth. They had the advantage over us in that they have National Parks. There was another local area, Roseland, [which] was considering a similar policy. We consulted with them. In the end, they were in advance of us and they decided to pull out, but we decided to keep it [Policy H2] in because we got the message that that was wanted (SO1 [p1]).

Adopting a 'principal residence clause' in St Ives was viewed as a more effective means of improving housing market access than stipulations concerning 'local connection' or [minimum] 'length of residency'. Members of the Housing Topic Group contended that through the clause they would be able to tackle the blight of homes being left empty during the low season and its negative impacts on residents: '[...] you get streets where there's only one resident and then they decide to move out because they feel a bit isolated and afraid at night' (S01 [p3]). The logic of the approach, from the policy team's perspective, was less about providing 'homes for locals' than simply ensuring that homes are lived in:

Any new building should be lived in as a home; therefore, it's only for people who are actually living here. That could be people who live here already [...] or it could be 
somebody from the rest of the country who wants to come down. It is, in part, to meet this local need, but we're restricted - and this is just a planning document - we can't force who these houses are given to ( $\mathrm{SO1}[\mathrm{p} 3])$

However, there was greater support for policy $\mathrm{H} 2$ amongst households that were relatively new to St Ives than from the town's long-term residents. This suggested different interpretations of the intended purpose and likely impacts of the clause. The reasons for diverging levels of support, and different attitudes to 'holiday lets', were reflected on be a member of the Housing Topic Group:

There was [in consultation responses] possibly more support from people who are brought up here for things like holiday lets that were going to bring an economic benefit to the area than there was from incomers and [...] there was probably a divide there (S01 [p2])

Those dependent on the local economy for their livelihoods worried that $\mathrm{H} 2$ might lead to a loss of outside investment and income from tourism. Others - including retired households - deriving their incomes from other sources prioritised the maintenance of 'local character' and environmental quality over economic issues, though the defence of property values seemed to have been an important factor shaping their attitudes towards the clause. This was confirmed by a local estate agent: 'some people I've spoken to who voted for it [policy H2] said they're going to vote for it because it's going to put the price of their own house up' (S03). The referendum held in St Ives, however, was intended to gauge local support for the whole Neighbourhood Development Plan - with its fifty policies covering a range of topics - rather than just Policy H2. Another of the town's estate agents doubted whether many of those voting in the referendum 'had read anything about H2'. He was sure, however, that 'the developers did and the builders did, and they were all against it' (S05). But because the referendum's focus was the NDP rather than any particular policy, strong support for the adoption of the plan does not automatically imply commensurate support for H2. This was acknowledged by the Housing Topic Group: local housing access had been identified as an important challenge for the town during public consultations in 2013 , but no solutions were forthcoming at that time. Therefore, a small sub-committee 
- the HTG - took it on itself to develop a policy response that was not subject to further consultation. One of the group's members felt that, in light of the importance of $\mathrm{H} 2$ (or possibly because of the controversy it courted), the policy should have been the subject of its own referendum. That view that the mandate delivered by the referendum should be more content-specific - was countered by the argument that $\mathrm{H} 2$ was simply an evolved version of previous local policy. Occupancy restrictions had already been included in the Penwith District Plan (but deleted in 2009) and in previous iterations of the Cornwall County Council Plan. Moreover, it was suggested that the inclusion of $\mathrm{H} 2$ in the Neighbourhood Development Plan would merely result in the trialling of a novel policy approach that was likely to have limited impact. Of the 1,100 homes allocated to St Ives in the 2010-2030 Cornwall Local Plan, 750 had already been delivered: meaning that the principal residency clause would apply to just 350 homes allocated under the current local plan over the next 12 years. This point, it was claimed, seemed to have escaped the media - and was an important factor behind the Town Council's decision to include H2 in their Neighbourhood Development Plan (S01 [p1 \& p3]).

One persistent concern, common to all such occupancy or residence restrictions, is the long-term enforceability of the approach - whether loopholes may be found that undermine the aim of increasing levels of full-time housing occupancy. 'Principal residence' (as opposed to 'secondary residence': i.e. a second home) does not automatically equate to full-time or even regular occupancy. It would be possible, for example, to register for Council Tax in a property subject to Policy H2 but then live more regularly in another property, located elsewhere, which has been declared a second home for tax purposes. The Neighbourhood Plan Steering Group suggests that this issue could be addressed by broadening the scope of 'verifiable evidence' to include registration on electoral rolls or with a GP; or of course having children attending local schools (St Ives ANPSG, 2015a). Interviews, however, suggested that the collation of such evidence may not be necessary. The presence of a legally enforceable planning restriction is likely to dissuade prospective purchasers from 'gaming' the system (S06) in the first place and where breaches are identified, there was an expectation that these could be dealt with effectively. 
It was considered vitally important that the Town Council sent out the right signals in relation to its priorities for housing in St Ives. Members of the Housing Topic Group conceded that although Policy $\mathrm{H} 2$ might not be the 'ideal' means of raising levels of housing occupancy and easing access - and that enforcement complications and uncertainties might arise - the chance to formulate a Neighbourhood Development Plan after 2011 provided politicians with an irresistible opportunity to demonstrate action on a 'hot topic' of pressing concern to local voters. In relation to broader housing market pressures:

We are limited in actually what we can do and we're aware that this is an experiment and there will be a five-year review and it may well be that some other neighbourhood plan will come up with even better mechanisms which we can incorporate at a later stage. This is a learning process - we'll see how it goes (S01 [p2]).

\section{The logic of intervention: experiment or appeasement?}

The strategic intent of Policy H2 - to improve local housing access and increase occupancy - is to be achieved by preventing speculative or contract new-build for external clients, wishing either to acquire second homes or investment properties in St Ives (S01). It does not, overtly, aim to make housing more affordable or deliver affordable housing products. This is the goal of a separate Policy H1, which seeks contributions from developers to the delivery of non-market housing - through standard Section 106 agreements. The two policies will inevitably work together, altering the context for housing development in the town: $\mathrm{H} 2$ restricts the occupancy of all new housing (cutting out the external component of the wider housing market) whilst $\mathrm{H} 1$ imposes an additional development cost in the form of a Section 106 contribution. All new housing is for 'full time residence' but some will be for households on lower incomes, drawn from local waiting lists or eligible for special support.

But whilst the policies are meant to work together, there is a danger that they will work against one another. If residual land values fall (see Figure 1) because of the market restriction (H2) then insistence that sites still deliver affordable housing contributions (H1) will render development unviable. Restrictions on higher-income buyers entering the market (who hitherto helped bid up land and property prices) will reduce the carrying capacity of housing sites. Those sites may therefore not come forward 
for development at all, or if they do they will not be able to carry affordable housing contributions (S07).

Interviewees from the real estate sector drew attention to reduced housing supply as a general risk with all such market restrictions (i.e. sites not coming forward at all). This was seen as a particular danger in St Ives where, as one estate agent noted, '[...] probably $60 \%$ - maybe $70 \%$ - of the property that we sell is to second home owners or boarding [holiday] home owners' (S03). Pent up demand was expected to be vented into the second-hand market:

There's an argument that what they've done will actually drive prices up because the chances are that there are going to be more people who want to buy holiday homes/second homes and retire down here [in the future], but the market is now limited and where a market's limited, prices tend to go up (S04).

Policy H2 seemed to create a more challenging context for Policy H1 and, more generally, real estate sector respondents questioned whether (housing) market restrictions could address the more fundamental reasons why local buyers were often out-competed in the housing market - i.e. lower earnings relative to those of external buyers (S04). A number of ways in which $\mathrm{H} 2$ could worsen local housing access were suggested. If external demand refocused on the second-hand property segment (see Figure 1), then the current stock of rental property might be depleted - if higher prices within that segment encouraged owners to sell to external buyers (S05). Windfall sites were also thought to be at risk, if the market weakened, land values fell and incentives to bring such sites forward were reduced (S07).

Given their particular interest in the operation of the housing market, and securing commission from property transactions, the gloomy predictions of estate agents are perhaps unsurprising. The planning officer, however, was more circumspect on the prospective impacts of Policy H2. A slump in housebuilding need not result in an overall reduction in affordable housing delivery as opportunities remained to deliver such homes on 'rural exception' sites (S06). The same officer also knew that the restriction would affect only a limited number of new-builds: up to 300 permissions during the current 
local plan period (to 2030). This reality added to the sense that $\mathrm{H} 2$ would be a time-limited experiment, with impacts monitored and the policy adjusted, at some point in the future, if necessary. Support from the Neighbourhood Forum - for the more 'radical approach' that $\mathrm{H} 2$ represented - was also grounded in this reality. It was thought that experimentation with those 300 permissions could not end in catastrophe given the relatively modest effect that $\mathrm{H} 2$ was likely to have on the housing market: over the next decade, speculative development would be curbed and emphasis would be placed on delivering affordable housing, from exceptions and through contributions from developers. The ambition for parallel Policy H1 was considerable. One Housing Topic Group member set out the Town Council's intention to seek '[...] up to $100 \%$ [affordable housing] and if the viability test demonstrates that anything above $50 \%$ would not be viable, we would then say [that] it shouldn't be built' (S01 [p3]). The expectation was that even in a constrained market, private developments would still be able to carry and deliver considerable Section 106 contributions, presumably because gross development values would be unaffected by $\mathrm{H} 2$. Town Council respondents did not believe that $\mathrm{H} 1$ and $\mathrm{H} 2$ were in any way incompatible.

Rather than being a 'radical approach' to dealing with development and market pressures, H2 was thought by expert respondents to be a means of 'appeasement' (S09); political theatre aimed at pleasing local voters, but built on a flimsy evidence base and not rooted in any appreciation of development economics. Its purpose was to show resolve. Media reporting in the year of the referendum presented H2 as a 'second homes ban' (BBC News, 2016; Telegraph, 2016) and whilst this provoked anxiety amongst some local businesses, it drove home the message that the Town Council was prepared to confront market pressures. Numerous interviewees agreed that $\mathrm{H} 2$ was an important symbolic act - a mix of appeasement and experimentation that responded to local symptoms of a wider housing crisis. That crisis was manifest in St Ives by new housing being let to holidaymakers as soon as it was built. When this happened on a recent scheme, a line was crossed and 'something had to be done' (S01 [p2]). Neighbourhood Development Plans provided the means to 'do something'.

\section{The Evidence Base}


Whilst the Housing Topic Group took inspiration from policies implemented or being developed elsewhere, it had not examined any studies of longitudinal impact (of the type undertaken by Capstick (1987) and Shucksmith $(1981 ; 1990)$ in the Lake District). These studies are not widely known outside of academic circles and governments (which have in the past taken a view on market impacts) tend to have short institutional memories which do not extend beyond one administration. Hence there is constant return to past policy and initiatives, even if doubt has previously been cast on their efficacy. The expectation that the HTG or the Town Council might have reviewed such studies was possibly fanciful. That said, local actors were generally aware from the sorts of impacts that an H2-type intervention might produce in the land and housing market and therefore the effects it might have on development pace, market segmentation and housing affordability.

4. Observed and Anticipated Impacts: 'If every town adopted the same policy, it might start making a difference'

Expectations of what might happen, for good or bad, provided the underlying logic of action described above. Proponents of the restriction argued its potential would be explored through a limited experiment that would affect relatively few development permission. Opponents, on the other hand, believed that development would grind to a halt with nothing being built 'for quite a while' (S10). The expected suppression of land values could jeopardise the viability of schemes, impacting on the inclusion of affordable housing within market schemes (S03). Whilst respondents on different sides of the argument often agreed that it was too early to discern actual impacts, one local developer claimed that land market impacts are already being felt:

One of our consents got caught on the wrong side of the H2, which means that it [faces] a double whammy - the 40 per cent on site affordable [contribution] and [...] the H2 clause applied. What's happened is that the site has stalled and it's stalled because the landowner expectation is higher than the market will be prepared to buy that land from him at, which is to do with a lack of confidence (S07). 
Getting the market moving again will, it was argued, require that land owners accept lower sale prices (that will only happen over time) (S07) or planning and development briefs are revised to allow more housing, at higher density, on sites with outline permission. Those sites need to be returned to viability (S06) in light of the changed policy context. But neither of these adjustments seem likely: landowners are more likely to sit on the small number of infill sites (within settlement boundaries that are suited to housing development) until policy changes or the market changes and price expectations are met. And moves to increase densities (through alternative housing typologies) is likely to provoke considerable local opposition, threatening the character and amenity that $\mathrm{H} 2$ is supposed to protect. Given these tensions, the expected outcome is that some sites will struggle to get off the ground and there will be a deceleration of development pace (S06, S07). This will happen not only because of broader concern over site viability, but because developers worry that occupancy conditions represent a 'burden on title' for prospective homebuyers trying to securing mortgages on new-builds subject to the $\mathrm{H} 2$ restriction. Whilst Housing Topic Group members argued that banks have a track-record of lending on properties with similar restrictions elsewhere (S01), such potential complications may cause some housebuilders to re-assess risk and potentially avoid such projects.

The development industry was said to be important for St Ives, sustaining a circulation of money that supports a number of local tradesmen:

There's quite a lot of building going on and I have no idea how many trades are working in St Ives at the moment, but they all come into town, they go and get a coffee in the morning, they go and buy some lunch at lunchtime, they stop off for a pint on the way home. When all those tradesmen stop working in St Ives, the money that they're spending in St Ives is going to stop too (SO4).

The anxiety expressed here may capture a real concern but it is difficult to size this potential impact. Other studies of second home ownership suggest that concentrations of second and holiday homes often support an eco-system of maintenance activity: small businesses engaged in gardening, decorating, cleaning, property repairs, management and small-scale building projects (Gallent et al, 2005). These 
homes become an economic life-line during the low-season when repairs and maintenance is undertaken ahead of the arrival of owners and guests (S10). Given St Ives' relatively remote location -well away from major centres of population - many owners of second homes are likely to live outside the "weekend zone' (Hall and Müller, 2004). They will not visit regularly and undertake their own maintenance, rather relying on the services of local businesses and tradesmen. However, although this aspect of the tourism economy may be impacted upon by the occupancy restriction, its impact on development pace may help preserve the place qualities that draw visitors to the area (S08). That impact will depend on the degree to which character was being degraded by development prior to the intervention compared to the effect of the policy on the level and type of new housebuilding following the introduction of $\mathrm{H} 2$. The evidence needed to make that comparison is limited, although some glimpses were afforded by interviews.

At the beginning of 2017, two residential projects were said to have been affected by the occupancy restriction. The first, a new-build project with a gross development value of between $£ 5$ and $£ 6$ million had stalled because of uncertainty around the impact of $\mathrm{H} 2$ on the saleability of units (S07). In the second case, investors had pulled out of planned 'build and replace' projects because of cost uncertainties on these previously-developed windfall sites (S09). These examples could point to lasting impacts on the propensity of development to come forward. On the other hand, they could simply signal that developers and investors are 'finding their feet': getting used to new rules and trying to figure out their implications for development (S07). Their cost and risk assessments will eventually accommodate the new policy, as regularly happens when planning rules and regulations change (see de Magalhaes et al, 2018).

There is, however, a broader perception of market change linked to $\mathrm{H} 2$ and the Neighbourhood Development Plan. Media reporting has drawn attention to a reported 10\% fall in enquiries to estate agents from potential investment and second home buyers. This has been linked to a feeling that 'outsiders have been made to feel unwelcome' (Telegraph, 2016). But data here are again limited. In the days following the 2016 referendum, some parts of the press was keen to find corroboration for the view that market restriction was bound to generate its own problems for the area. Estate agents, 
perceiving a new threat to their own businesses, were ready to confirm those expected problems. It is difficult, however, to untangle the impact of local politics on market confidence from the broader impacts of national politics. The referendum on the UK's membership of the European Union took place just a month after St Ives' own referendum (S02). Equally, changes to stamp duty payable on second homes, and also to the rate at which tax relief can be claimed on rental income, have also impacted on the housing market across the UK. Despite the linking of some local development failures to Policy H2, the majority of those interviewed did not anticipate major changes to either housebuilding or the local economy - or at least not changes that would have broad effect on a cross section of people. One of the respondents made the following prediction:

I don't think a lot is going to change drastically. We're still selling second homes to second home buyers. It's just that there's not going to be the new properties for people to buy. So I think the economic impact will be [...] that house prices will increase, probably far and above the national average (SO3).

Average property prices for St Ives and for England \& Wales during the last four years (two years before and two years after the NDP referendum) are tracked in Figure 2. These are Zoopla's summary presentation of Land Registry transaction data (sale prices). Average prices in St Ives were $£ 50,000$ above the national average in the beginning of the period. The gap narrowed during 2015 and 2016 (to around $£ 10,000$ ) before widening again throughout 2017 and into 2018. Aggregate national data are more reliable than small area data, which rely on fewer transactions. Nevertheless, a pattern emerges which might be explained by the restriction of available supply (to the wider market) in the new-build segment and the transfer of demand, and price pressures, to the second hand market (see Figure 1). 


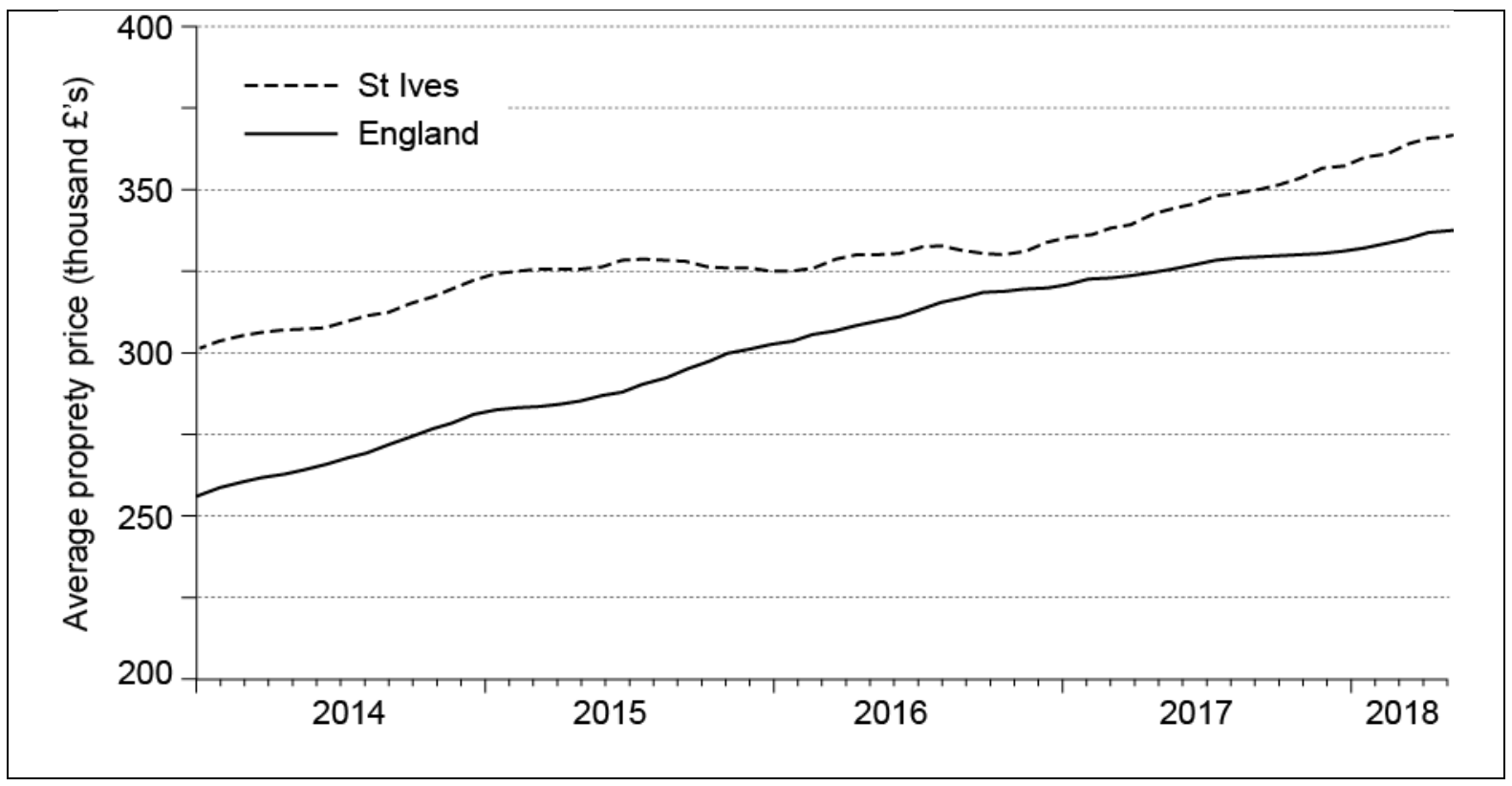

Figure 2: Average property prices (2014-2018) at St Ives and across England (Source: zoopla.co.uk)

Supply in the new-build segment responds to demand, being impacted upon therefore by the full-time residence restriction (S10). Over in the second-hand segment, demand rises. This happens either because overall demand remains constant and needs an outlet or because overall demand rises in response to the policy (and needs an outlet). The policy causes scarcity (of opportunities for investors) and scarcity drives up capital appreciation (assuming the queue of investment buyers remains the same or lengthens). The most constrained markets in the UK, with clear locational advantages, are the most attractive to investment capital: London prime and, in areas of countryside, locations enveloped by AONBs and National Parks. In those locations, investors know that the value of their asset is less likely to be denuded in the future by increased supply and decreased exclusivity. Restrictions like $\mathrm{H} 2$ are a green flag to investment capital.

At the moment, it appears that falling supply is not driving up house prices: there are certainly 'no shortage of planning applications' in St Ives (BBC Countryfile Magazine, 2018). Rather, strong demand has continued, and has been focused in the second hand market. Transactions in that segment generally have the greatest 'price setting' effect as new build, and new build transactions, are a relatively small part of the wider housing market in the majority of locations. A slowdown in construction might occur in the future (if developers and their investors encounter reduced demand for new build within 
their target price markets) but the use of land for housing (relative to alternative uses) is likely to remain profitable even if gross development values and hence land values decline. Also, developers may be limited in their choice of alternate development locations in and around Cornwall's prettiest coastal towns and villages: a number of other places in the south west have expressed interest in, or even made steps towards, implementing their own restrictions. 'If every town adopted the same policy, it might start making a difference' (S04). But what difference would it make? An upscaling of H2 across a region that is hugely attractive to investment buyers will drive investment scarcity and potential investment value: unless there is hostility to those investors, and this is enough to dissuade the majority from entering the market, Cornwall will become a far more attractive destination. The pace of development is likely to slow, protecting landscape amenity and village character, but 'local housing accessibility' could become more dependent on the new-build sector, which will face disruption from changes in the land market and developer interest.

This future now seems possible. A number of similar policies are being introduced in NDPs (see Figure 3). St Minver and Rame have done so and Mevagissey is exploring its options (Telegraph, 2018). Roseland introduced its own policy but was forced to backtrack and turn this into a 'statement of intention' when insufficient evidence to support its restriction was presented. Although the impacts of St Ives' policy are as yet locally unclear, what is clear is that NDPs are now viewed, in some quarters, as a vehicle for re-engineering local housing markets. Although Lynton and Lynmouth's 'Lynplan' (2015) predates the St Ives initiative, the latter marks the transfer of such policies outside a National Park setting. Inside the Parks (including the Lake District in the 1970s), the 'honeypot' effect is thought to accentuate housing market pressure and justify special measures. But outside the Parks, the broader issue of 'community sustainability' remains in the face of strong external housing demand. This has been St Ives' argument - and it has been generally accepted. 


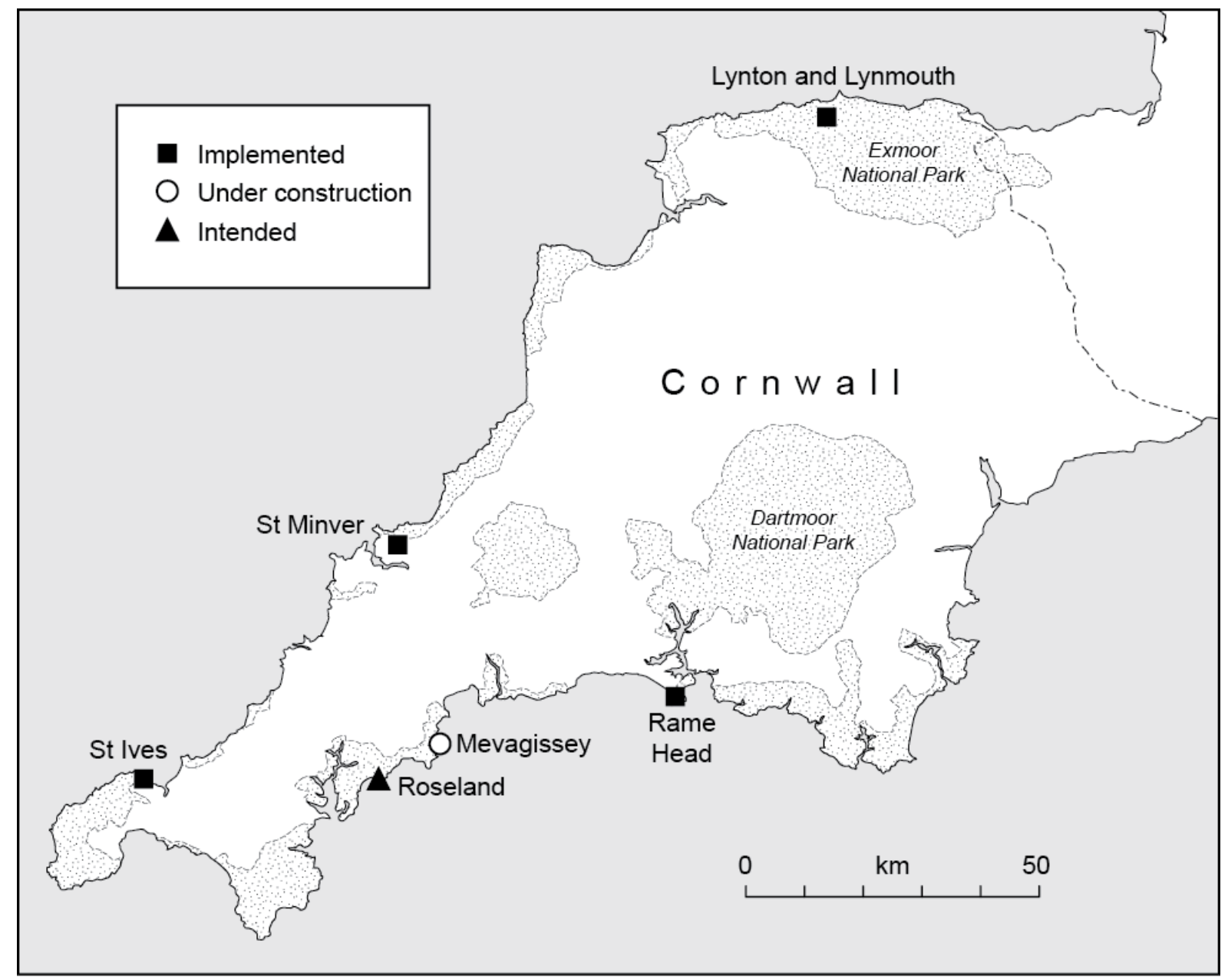

Figure 3: Locations in Cornwall with residency restrictions implemented, under construction, or intended

\section{Market Segmentation}

Finally, interviews explored market segmentation. Planning restriction acts on the new build segment, potentially controlling the occupancy of new homes through the use of conditions or restrictive covenants. The current system cannot regulate the onward sale or use of existing homes that are free of condition or covenant. This means that rather than bringing 'balance' to the market (ensuring fairer or more equitable access to all housing), by acting only on the new build segment, there is a possibility that fewer new-builds will happen (see above) and the price-setting effect of transactions in the market for existing homes will be enlarged. The queue of buyers for new property will shorten whilst the queue for existing property lengthens, as external demand shifts to that segment of the market that remains open to it. This is the theory depicted in Figure 1. Planning intervention was described by one critic of 
$\mathrm{H} 2$ as a 'meat cleaver', brought to bear on a nuanced issue (S07) and unable to address the complexities of under-occupancy and the desertion of some streets, which blights St Ives during the low season. Indeed, by concentrating second home demand in the existing town (rather than on out-of-town newbuilds) it risks worsening this problem. Those who supported $\mathrm{H} 2$ were also critical of its limitations: some wanted to see the development of a wider strategy, at national level, that would allow local planning to control broader patterns of occupancy across the new-build and second hand segments of the market, thereby dealing more evenly and consistently with potential price distortions. Returning to territory that has been trodden many times during the last 40 or so years, it was proposed that the Use Classes Order (listing changes in land uses requiring planning permission) could be used to distinguish between homes occupied on a full-time basis or seasonal basis (see Gallent et al, 2005: 168). No home currently judged to be in 'full time occupancy' (a new stipulation for 'C3' use) could be occupied seasonally ('C3d') without planning permission. Every time the problem of market segmentation is raised in relation to broader use of occupancy conditions, the response is to propose a use class adjustment. It was proposed by Welsh nationalists in the 1980s and by a Labour MP in the 1990s, only to be described by the Conservatives as 'spiteful and impractical' (ibid, 168). The Scottish government commissioned a report into the approach a decade ago, which concluded 'definition difficult, implementation problematic' (Satsangi and Crawford, 2009). More recently, the Conservative Government has been unequivocal in its rejection of all such restrictions, with the former Housing Minister Brandon Lewis, declaring that ' $[\ldots]$ owning property is a human right and a fundamental British liberty $[\ldots]$ trying to control private ownership via the planning system will require intrusive inspectors to monitor the usage of every home and state surveillance of every property' (Planning Advisory Service, 2015). Over the last decade, the level of owner-occupation in England has fallen from $68 \%$ in 2007 to $62 \%$ in 2017 . Government is struggling to deliver this particular 'human right' for everyone as investors - including second home buyers in St Ives - consume greater quantities of housing, leaving less for those households whose aspiration is merely to own the home they live in (see Dorling, 2015).

\section{Conclusions}


We began this paper with two broader propositions. Firstly, because housing outcomes are 'shaped upstream of local intervention', those interventions sometimes amount to little more than political theatre in which the presented ambition of altering market outcomes cloaks a more prosaic goal - to protect local amenity. Secondly, local planning tools do not provide effective means of shaping housing outcomes that have much deeper structural underpinning, and therefore risk a variety of unintended consequences.

First, local government must inevitably deal with the fall-out of decisions taken 'upstream'. Market economies are structured by the regulatory frameworks put in place by supra-national and national bodies. For housing, these include banks deciding to preferentially lend on land and property (RyanCollins et al, 2017) and governments deciding to promote property ownership through relatively low tax liability whilst deregulating bank lending and letting the market set its own level of property consumption. These decisions have resulted in the free flow of investment into housing in recent decades, manifest in many local phenomenon: the arrival of international buyers in cities like London, the growth of amateur landlordism, in the form of 'buy to let, and the purchase of second homes in some of the most attractive locations in England. Of all housing investment strategies, second home buying is one of most well-established - and places like St Ives have experienced its plus and negative sides for many decades. Across all types of investment, a consumption 'tipping point' has arguably been reached in the last few years, causing the level of owner-occupation to dramatically dip. Almost $70 \%$ of households in England owned the homes they lived in a decade ago. The proportion today is closer to $60 \%$. Local government is well-placed to observe the implications of this shift: local people on average wages struggling to buy their own homes, often living in expensive rented accommodation of the wrong type and poorly located. In the meantime, towns like St Ives fill up with second-home owners in the summer and then become ghost towns in the winter. Remaining residents look to local government - the Town Council in this case - for action. Saying that global and national forces are at work is not an option for a 'local authority' with designated housing and planning powers: it must do what it can to confront those forces, irrespective of its misgivings. 
Local government needs to be seen to act. When the challenge faced is one of 'non-local' buyers consuming the local housing resource, the obvious answer is to introduce new restrictions. But the general freedom of the market, captured in the UK Housing Minister's comments, means that demand will 'find a way'. All past restrictions in the occupancy of new-build housing have been accompanied by a transfer of demand to the second-hand sector. Whilst local government engages the rhetoric of restricting local occupancy, national governments respond by reasserting general property rights. There is an element of political theatre at all levels, with politicians speaking to their core constituents, either local voters or investors, whose support for the property market is sought by government. Any move to restrict the freedom of private property would send a tidal-wave of alarm through the housing sector: government needs to offer its own assurances.

There appears to be an irreconcilable friction between the objectives of local and national bodies: whilst the former seeks, ostensibly, to carve more equitable housing outcomes from problematic structures, the latter supports those structures by reasserting private property rights. But are they so out of sync? Property values are sustained, in part, by public interventions that support infrastructure and amenity. Local authorities in the UK's most scenic rural areas are charged to balance amenity and landscape protection objectives with the promotion of economic development and support for a well-functioning housing market. These objectives are difficult to separate, especially where tourists consume much of the available housing resource and additional development is needed, which could conflict with amenity and landscape objectives. One final thought on the predicament at St Ives - from S06, the county council planner - was that all settlement boundaries should be redrawn, much more tightly. This would greatly restrict speculative development (to infill only) and result in reliance on 'exceptional' planning permissions for new affordable housing. This seems to us to shift the balance further, and too far, towards amenity protection. Rural authorities are already doing much to sustain the private property value in rural areas, through their emphasis on amenity protection. There is clear injustices in existing patterns of housing consumption, but until these are shifted through national structural change, attempts by local planning to restrict development (including inadvertently though occupancy restriction) are 
likely to add to those injustices, increasing house prices and squeezing working households from rural markets.

Second, and finally, past research has already pointed to the unintended consequences of planning restriction aimed at targeting local needs in rural areas. The previous longitudinal studies, referenced earlier in this paper, show how distortions arising from external demand sources may be magnified within the second-hand market, thereby decreasing overall housing affordability and access. Land use planning is not the silver bullet for rural communities looking to solve their housing dilemmas. Upstream action is needed that supports not the human right to owning property (in any desired quantity) but the universal right to a secure and stable home, so often undermined by the sorts of housing consumption pressures seen in St Ives.

\section{Acknowledgement}

To be added

\section{References}

BBC (2016) High Court rules second homes ban in St Ives will remain, $10^{\text {th }}$ November 2016. Available at: http://www.bbc.co.uk/news/uk-england-cornwall-37938885

BBC Countryfile Magazine (2018) What is the impact of second-home ownership in rural Britain? BBC Countryfile Magazine, $23^{\text {rd }}$ January 2018. Available at: http://www.countryfile.com/article/second-homeownership-problem

Capstick, M. (1987) Housing Dilemmas in the Lake District, University of Lancaster: Centre for North West Regional Studies

Department of the Environment (1981) Proposed Modifications to the Cumbria and Lake District Joint Structure Plan, DoE: London

Dorling, D. (2015) Inequality and the 1\%, Verso Books: London

Edwards, P. (2016) Planning: blocking second homes in St Ives, Law Gazette, 16 May 2016, Available at: www.lawgazette.co.uk/law/practice-points/planning-blocking-second-homes-in-stives/5055252.fullarticle 
Gallent, N. and Bell, P. (2000) Planning exceptions in Rural England past, present and future, in Planning Practice and Research 15(4), 375-384

Gallent, N. and Robinson, S. (2011). Local perspectives on rural housing affordability and implications for the localism agenda in England, in Journal of Rural Studies, 27(3), 297-307.

Gallent, N. and Robinson, S. (2012). Community perspectives on localness and 'priority' housing policies in rural England, in Housing Studies, 27(3), 360-380.

Gallent, N., Tewdwr-Jones, M. \& Mace, A. (2005) Second Homes: European Perspectives and UK Policies, Ashgate: Aldershot

Gallent, N., Hamiduddin, I., \& Madeddu, M. (2013). Localism, down-scaling and the strategic dilemmas confronting planning in England. Town Planning Review, 84(5), 563-582.

Gkartzios. M. and Ziebarth, A. (2016) Housing: A Lens to Rural Inequalities. In: Shucksmith, M; Brown, D, ed. International Handbook of Rural Studies. Routledge, pp. 495-508.

Hall, C. M. and Müller, D. K. (Eds.). (2004). Tourism, mobility, and second homes: between elite landscape and common ground (Vol. 15). Channel View Publications.

Hilber, C., and Schöni, J. (2016). The Housing Market Impacts of Banning Second Home Investments. London School of Economics, Centre for Economic Performance \& Spatial Economics Research Centre.

Jackson, A., Monk, S., Royce, C. and Dunn, J. (1994) The Relationship between Land Supply and Housing Production, Joseph Rowntree Foundation: York.

Lake District Special Planning Board \& Cumbria County Council (1980) Cumbria and Lake District Joint Structure Plan - Written Statement, LDSPB \&CCC: Kendal

Lake District Special Planning Board (1977) Draft National Park Plan, LDSPB: Kendal

McCann, D. (2015) Independent Examiners Report on the St Ives Neighbourhood Development Plan, St Ives: St Ives Town Council

Milbourne, P. (2004). The local geographies of poverty: a rural case-study. Geoforum, 35(5), 559-575.

Planning Advisory Service (2015) Advice from Planning Advisory Service in regard to second homes. Available at: https://www.dorsetforyou.gov.uk/media/207891/Planning-Advisory-Serviceadvice-on-second-homes/pdf/Second_Homes_Advice.pdf 
Robertson, R.W. (1977) Second home decisions: the Australian context, in Coppock, J.T. (Ed) Second Homes: Curse or Blessing? Pergamon Press: Oxford.

Satsangi, M., \& Crawford, J. (2009). Investigation of Occupancy Controls in Rural Housing. Scottish Government Social Research.

Shucksmith, M. (1981) No Homes for Locals? Farnborough: Gower Publishing

Shucksmith, M. (1990) Housebuilding in Britain's Countryside, London: Routledge

St Ives Area Neighbourhood Plan Steering Group (SIANPSG) (2015a) St Ives Area Neighbourhood Development Plan 2015-2030, St Ives: St Ives Town Council

St Ives Neighbourhood Plan Housing Topic Group (St Ives NPHTG) Minutes of the Meeting held on 15 January 2014.

Telegraph (2016) St Ives second home referendum backfires as housing market slows because outsiders don't feel welcome, estate agents warn, Telegraph $1^{\text {st }}$ August 2016. Available at: https://www.telegraph.co.uk/news/2016/08/01/st-ives-second-home-referendum-backfires-as-housingmarket-slows/

Telegraph (2018) When your retirement home becomes your bolt-hole between holidays, 11 April 2018. Available at: https://www.telegraph.co.uk/property/retirement/retirement-home-becomes-bolt-holeholidays/

The Guardian (2016) St Ives backs residents-only home ownership plan in referendum, The Guardian, 6 May 2016, Available at: https://www.theguardian.com/uk-news/2016/may/06/st-ives-cornwall-backs-residentsonly-home-ownership-plan-referendum

Zoopla (2018) Area guide for St Ives, Cornwall (accessed 29 $9^{\text {th }}$ April, 2018). Available at: https://www.zoopla.co.uk/market/cornwall/st-ives/?q=st\%20ives

St Ives Town Council (2016) St Ives Area Neighbourhood Development Plan 2015-2030, https://stivesnplan.files.wordpress.com/2013/08/final-st-ives-area-ndp.pdf

The Economist (2016) 'To the lighthouse: one seaside town in Cornwall is taking on the out-of-towner', in The Economist, 9 April 2016, www.economist.com/news/britain/21696553-one-seaside-town-cornwalltaking-out-towners-lighthouse 